Preliminary note

Primljeno: 09.06.2014

UDK: 316.73:811.111(4)

\title{
Intercultural Perspectives of the English Language in Europe
}

Sunčana Tuksar Radumilo, prof.

Interdisciplinary Study of Culture and Tourism, University of Juraj Dobrila, Pula

Department of Economics and Tourism "Dr. Mijo Mirkovic", Correspondence concerning this article should be addressed to Sunčana Tuksar

Radumilo, prof. Interdisciplinary Study of Culture and Tourism, University of Juraj

Dobrila, Pula.

Email: stuksar@unipu.hr

\begin{abstract}
The aim of this study is to draw attention to the change of EL usage from a global lingua franca which has been removing the language barriers to a new cultural phenomenon that is used to enforce the penetration of different cultures and to ensure their promotion. Thus, it is a necessity to tackle the subject of up-to-date and diverse cultural contents brought to Europe via the internet and its implications on the language.

The example of Asian pop-cultural phenomenon will be provided. It has been viewed and examined via the survey conveyed among the students of Juraj Dobrila University of Pula whose obligatory foreign language is English. They were subjected to a Personal Questionnaire created by this author in order to tackle the following questions: Do you think English will spread without end? Will countries outside the Anglophone group continue to learn English? What changes of English could we expect due to economic and social changes? The first two questions were answered positively by $61.6 \%$ and $64.6 \%$ of students. $64.6 \%$ of them believe there will be more changes of the English language as such due to dynamic changes that have been influencing it. In the end, students gave different reasons and opinions for their claims which have been further elaborated in this paper.
\end{abstract}

Key words: English, lingua-franca, internet, culture, survey.

\section{INTRODUCTION}

It has been argued that English is expanding as a lingua-franca but not as a mother tongue. The question has been raised if English will always be learnt. Nicholas Ostler is among those linguists who argue that technology will fill the need: "English will fade as a lingua franca, but not because some other language will take its place" (Ostler, 2010). Rather, English will have no successor because none will be needed as technology will provide the means to overcome the intercultural communication gap. This paper has the main objective to view the latter and argue in favour of other phenomenon: not only the influence of English will not decline due to technology, but it is technology itself that promotes EL as the means to fill both the cultural and linguistic gap. Therefore EL more than ever preserves its status as a global lingua franca, not losing it to technology but rather being enhanced by it. 
This paper provides the argument for the fact that a whole new aesthetic development due to the technology should be reviewed, whereas the usage of EL in a pop culture domain on the internet enforces the penetration of a non-European world (i.e. the Asian world) into a more European one. Thus, EL will not only preserve its status as a (somewhat transformed, and possibly changed) lingua franca (e.g. cyber English) but also modify its purpose into the subject that holds the key to a cultural success.

Furthermore, this paper contains the results of a survey conveyed in order to examine the attitudes of students concerning the latter - intercultural influences of the EL as a lingua franca on the internet and the sense of availability it brings to our homes. The study was conducted on a sample of students studying the English language at Juraj Dobrila University of Pula, whose obligatory foreign language is English. Their attitudes were collected as a result of lectures given by their lecturer Sunčana Tuksar Radumilo about the influence of the internet as the flagship of the popular culture elements from a non-native English speaking countries who use EL as a "soft power" (Nye, 2004) into a domain of the commercial phenomenology in order to penetrate with their own cultures and thus enforce EL.

In the words of Iyer (2000, in: Tuksar Radumilo 2013): „These days a whole new realm of exotica arises out of the way one culture colours and appropriates the products of another. And technology, too, compounds this... sense of availability". Accordingly, this paper views and examines how the (inter)cultural penetration of the non-European and non-native English speaking cultures influence other cultures, including the Anglo-Saxon ones, and how the internet perpetuates and enforces the popularity of EL and thus acts as a flagship of its significance as a lingua franca. The Asian song Gangnam Style (PSY, 2012) is provided and examined as an example of the commercial usage of the EL in order to promote one's own culture (i.e. Asian).

The aim of the Study is to conduct a survey on a sample of students studying the English language as the obligatory foreign language at the Interdisciplinary Study Programme of Culture and Tourism at Juraj Dobrila University of Pula. Prior to the survey, a series of lectures had been provided and panel discussions had been held by the course lecturer Sunčana Tuksar Radumilo. Students included in the survey were attending the first, second and third year of the pre-graduate course of Interdisciplinary Study Programme of Culture and Tourism. Their attitudes were collected as a result of lectures and discussions raised on the topics of the influence of technologies, especially the internet on the interculturality both promoted and provided by EL as a global lingua franca and a marketing "cash-cow" used for promotion of the less familiar and prominent cultures (i.e. those of the Asian world.) Regarding the results of the research, we may conclude that students believe EL will continue to spread and to remain the only lingua franca due to a need for communication, unstoppable technological advances, economic growth and the spread and influence of the popular culture from a non-native English speaking cultures which continue to use the EL in the domain of commercial phenomenology. The lectures and panel discussions were followed by the students' feedback in a form of a threequestion research study survey.

\section{METHODOLOGY}

\section{Participants}

The survey was conducted in the winter semester of the academic year 2012/13. The sample of 139 students of University of Pula were included in the research. The students included in the survey, whose obligatory foreign language was English, attended the first, second and third year of the pre-graduate course of Interdisciplinary Study Programme of Culture and Tourism at Juraj Dobrila University of Pula. The study complied with the ethical research principles: the informants were aware of the purpose of the study and they participated on a voluntary basis. The survey was conducted as a result of the discussions that had been held during the panels and to express the opinion of students created after having been subjected to the series of lessons on the 
subject in question. The students' consent was obtained before recording the information. The average age of the informants was 19 .

\section{Measures}

The measure that was used in this study was the Personal Questionnaire created by the lecturer Sunčana Tuksar Radumilo as a follow-up to the lectures given in the English course on the topic of "From Lingua Franca to Gangnam Style" (Tuksar Radumilo, 2013).

This measure consists of three questions that encompass the lectures and panels as well as provide the opportunity for the feedback to the students. As a follow-up, the students were given a Personal Questionnaire which is of a three-fold nature in order to state and explain their opinion on the following questions:

1. Nowadays, English is the most successful language in the history of the world. Many think it will spread without end. What do you think?

2. The future of English is in the hands of countries outside the core Anglophone group. Will they always learn English?

3. We could expect the status of English to change during the unprecedented social and economic global changes. What do you think we could expect and what changes are we talking about?

\section{Discussion}

1. English is the most successful language in the history of the world. Many think it will spread without end. What do you think?

The panel discussion prior to the survey resulted in some facts: technology has had an enormous impact, but the cultures have been conveyed via the technologies (the internet) and they have too contributed to a change of perspective about the future of EL as a lingua franca per se. The students looked at the factors that enabled the rise of EL in the past, or any other lingua franca to that matter. Most commonly these have been conquest, commerce and conversion.

This paper provides the argument that EL still stands for a commerce-relevant lingua franca, or better yet, a "cash-cow", the means for almost immediate money flow. If we look at the second " $\mathrm{c}$ " in the three-fold nature of the mentioned above, the commerce, we may come to a conclusion that the learned language is not valued for its own sake, but only for the benefits that are gained from it, and only for as long as those benefits outweigh the costs. It is rightly suspected EL to be the last lingua franca, as Anglo-American hegemony withers due to the penetration of other cultures, thanks to the internet. But as for EL itself, it is the internet that made it that striking successful element in the realm of cultural businesses. The internet is not endangering English but rather enforcing it. The following (Graph 1) illustrates the results of the first research question tackled in this paper: 
Graph 1: Personal Report on Question 1

1. English is the most successful language in the history of the world. Many think it will spread without end. What do you think?

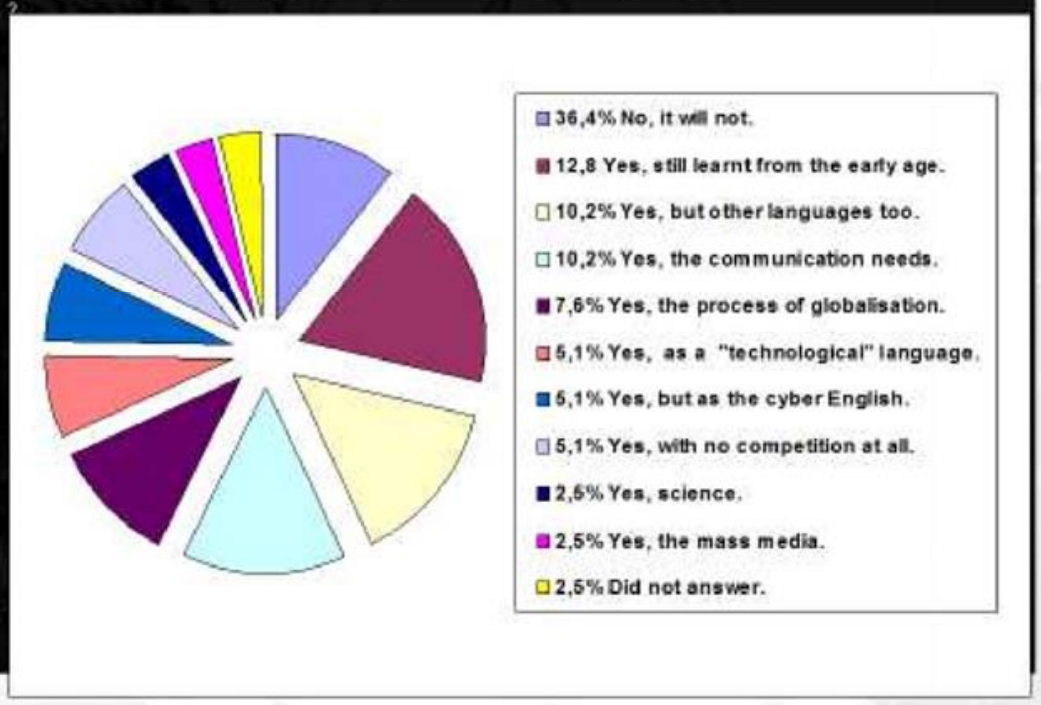

Only $36.4 \%$ of the surveyed students believe that EL will not continue to spread but agree with Ostler that technologies will fill the need and replace it as a lingua franca.

$2.5 \%$ of students did not answer.

However, most of the students, $61.1 \%$ of them, believe that EL will continue to spread as a global lingua franca for the following reasons:

- $2.5 \%$ believe it is due to the mass media influence.

- $2.5 \%$ believe it is the science that promotes EL the most.

- $5.1 \%$ of students believe EL will continue to spread without end because no other language provides a serious competition.

- $5.1 \%$ believe EL to be the lingua franca of the future, but in a new form of a cyberEnglish.

- $5.1 \%$ believe that EL will be a technological language. - $7.6 \%$ believe the process of globalization enforces EL.

- $10.2 \%$ due to communication needs which will not seize to be in English.

- $10.2 \%$ believe English will not seize to spread, but other languages will start to spread too.

- $12.8 \%$ believe the reason is the fact we still learn EL from the early age.

2. The future of EL is in the hands of countries outside the core Anglophone group. Will they always learn English?

Due to the dynamic interpretations that are setting global standards for the English language (EL) usage and education in Europe, Lee and Moody (2013; cf. Tuksar Radumilo, 2013) stated that "it has become crucial to engage in systematic interpretation of everyday cultural and linguistic practices of EL so many participate in". 
A new concept of promotion of culture was discussed providing the example of the Asian expanding circle (cf. Kachru, 1982) in the times when the culture becomes global, networked and digital. In this respect, the EL changes are by some referred to as "confusing concepts, due to true but also misleading facts and some otherwise guided attempts to make sense of many related, but distinct, trends in English on the internet" ("The internet and language change", 2012). The "something borrowed-something new system" (cf. Tuksar Radumilo, 2013) describes the mechanisms by which new words in EL are established, the most productive being the combination of existing words (cf. Dent, 2008; Tuksar Radumilo, 2013). Similar to this and due to technologies Europe and Asia have undergone an interactive process where a number of mixedand- matched compounds are created by borrowing the aesthetics. This further proves that there are no fixed trends any longer, and the versatility of cultures makes the number of possible combination infinite; as an example, there are the bizarre, almost fandome pop-culture blends such as the rockabilly breakdancers or cowboy robots.

The internet ruled for all cultures to come closer with their compilations due to the constant clicking and the appetite for new trends. Thus, EL is not only perceived as the "tool", or linguafranca, but is more and more used as a "bearer of the utter significance that bridges not only the linguistic, but also cultural barriers" (cf. Tuksar Radumilo, 2013). Accordingly, the second research question provided the following results (Graph 2):

Graph 2: Personal Report on Question 2

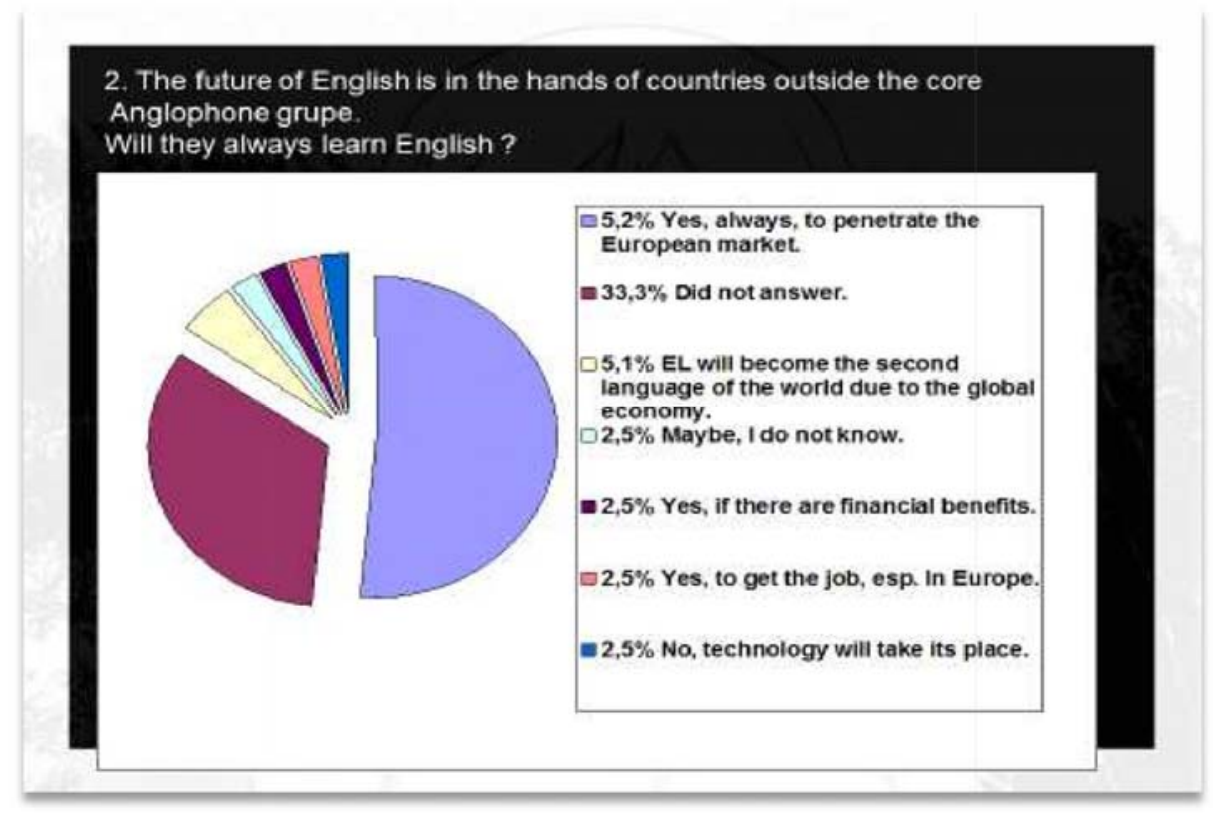

$33.3 \%$ of students did not answer, whereas $2.5 \%$ of students were not certain. However, most of the surveyed students, $64.6 \%$ of them, share the opinion that the future of EL is in the hands outside the core Anglophone group and that they will continue to learn it for the following reasons:

- $52 \%$ to penetrate the (Western, European) market.

- $5.1 \%$ due to the global economy.

- $2.5 \%$ due to the financial benefits.

- $2.5 \%$ to get the job, especially in EU. 
- $2.5 \%$ of surveyed students believe that technology will take its place and fill in the gap for the communication, as Nicholas Ostler claims.

3. We could expect the status of English to change during the unprecedented social, cultural and economic global changes. What do you think we could expect, and what changes are we talking about?

On the one hand, the Anglo-American mainstream monopoly that has been enforcing EL as a global lingua franca has now been transformed by the change of trends set by the internetinduced appetites for the constant clicking. What is more, the clear distinction between the European, sometimes referred as Western and non-European (i.e. Eastern) mainstream has been blurred out by some elements of cultural assimilation and adaption from one culture to another. On the other hand, however fast-growing and tremendously unpredictable the trends are, EL is firmly rooted and thus may be reviewed as a dependable element involved in (Asian) pop-culture in a form of a new "soft power" (Nye, 2004) that indicates the approval of a popular cultural product and keeps EL in the public eye.

As stated in the lecture and drawn from the paper "From Lingua Franca to Gangnam Style" (Tuksar Radumilo, 2013), students were given the example of a song "Gangnam Style" (PSY, 2010) to examine a recent example of a Korean pop- culture phenomenon "Gangnam Style" (PSY, 2012, ) in order to see how it falls into the category of the soft power concept defined by Nye ( 2004); According to a term "soft power" EL is used as such power to enforce the (Asian) culture via the internet and ensure its instant success.

What a country specifically needs to be a cultural superpower is a youth market with consumer clout and the EL as the eye-catching "bridge" to establish the product's "googleability" (Dent, 2008). And it still comes in the form and shape of a commerce lingua franca, for example products such as "Pokemon Hegemon" or "Hello Kitty". Thus, the results of the third research question have been as follows (Graph 3):

Graph 3: Personal Report on Question 3

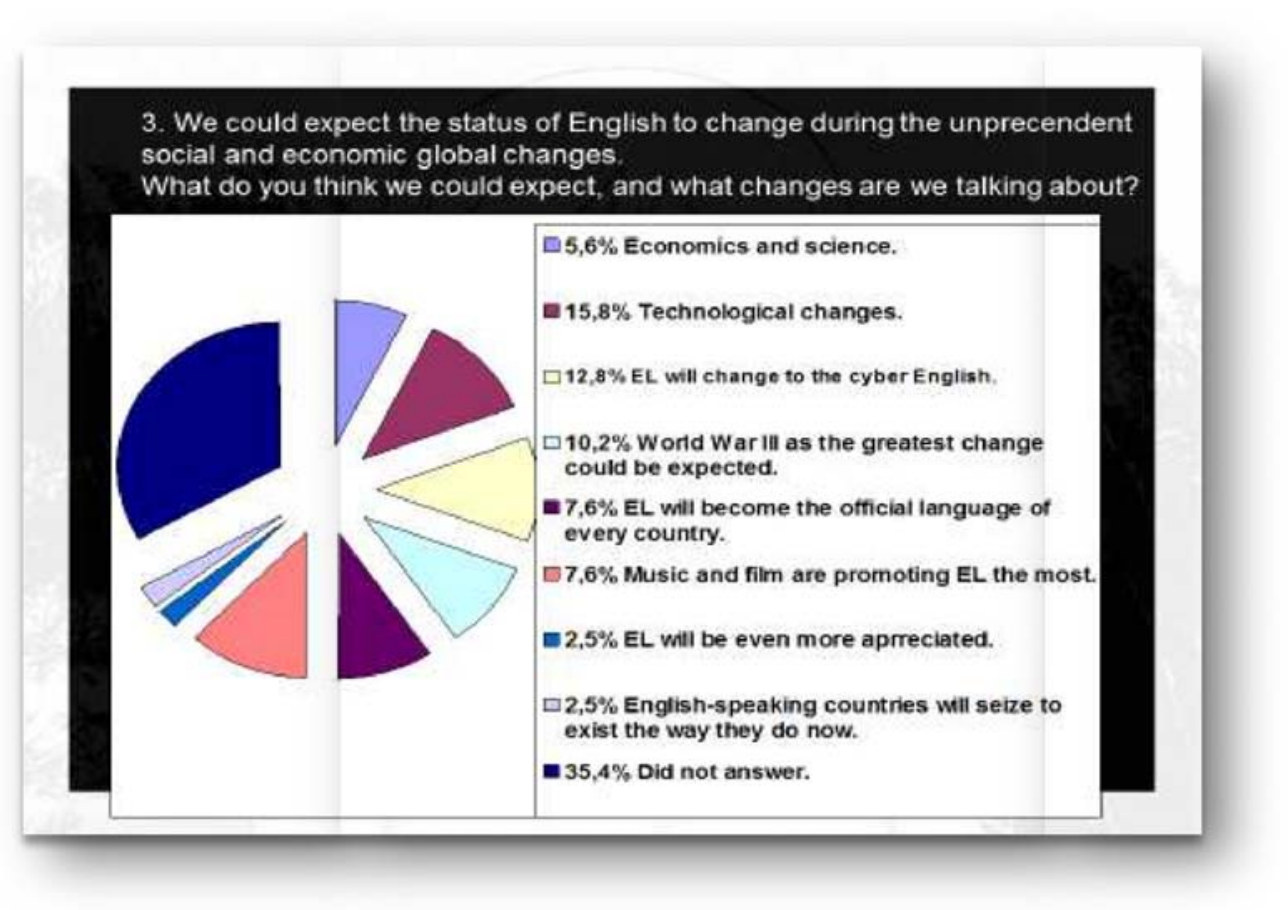


$35.4 \%$ of the examined students did not answer.

However, $64.6 \%$ of the students believe that it is the social, cultural and economic changes that would bring about the changes in the status of EL. All the students who answered stated their reasons for the change of the status of EL as follows:

- $5.6 \%$ due to the economical and scientific changes.

- $15.8 \%$ due to the technological changes (the internet).

- $12.8 \%$ due to the fact that EL will change and modify itself according to the nonEnglish speaking world, as a result, the cyber English will occur, adopted to different countries (cyber English may occur).

- $10.2 \%$ believe the WW3 will occur as the greatest global and social change and bring about something completely unpredictable. $-7.6 \%$ official language of every country $-7.6 \%$ due to the music and film.

- $2.5 \%$ believe EL will continue to be more and more appreciated due to the changes conveyed via the internet.

- $2.5 \%$ believe English-speaking countries will seize to exist as they are now and somehow merge together which will bring about the changes in the perception of EL.

\section{Limitation of the study}

One limitation of this study is that its scope is restricted to only three questions and to only such number of students; it should be interesting to consider whether the students of the English language as their Major would share these views too.

One way of expanding this research would be to consider how more similar examples affect students' apprehension of the future of English. Future research could include the larger students' groups, as well as consider whether the cultural influences of EL as a lingua franca and as a marketing cash-cow increase over time. More examples should be included in the lectures and study as the teaching the language should come hand in hand with socio-linguistic changes.

\section{CONCLUSION}

The signature dance moves were attempted by many notable political leaders such as a prime minister and a president of one country. Similar examples could be easily found in almost any media. Therefore it seems as if it would be out of place to question the (void in the) sociolinguistic cultural content of such international sensation and simply dismiss it as Mayers (2012) did by describing at as simply as an "inspired piece of silliness". Apart from the obvious marketing tricks that are typically involved in such songs, there is the category of the readiness to expand where EL steps in as one of the main references of success.

Although only the narrow image of a culture is conveyed in this way, it still plays an important role in bringing the language, and lifestyle to the rest of the world. Being a linguistic flagship travelling at its normal speed through modern times (Ostler, 2010), it may be stated that EL has arrived to a technological endorsement contract in the fast-forwarded internet campaign that brings an instant success to the pop-cultural products" of any of the less-familiar (Asian) worlds in a very specific way and via the more and more internet instant clicks" (Tuksar Radumilo, 2013). What is more, it proves how the socio-linguistic aspects influence the perception of EL as lingua franca. Thus the perspectives of EL in Europe should be examined and accompanied in the view of the parameters and reflections of socio-cultural changes that influence the language and its conveyance. 


\section{REFERENCES:}

1.) Dent, S. (2004). Larpers and Shroomers: the language report. New York: OUP.

2.) Dent, S. (2008). Words of the Year. New York:OUP.

3.) Foreign Policy. (2013). McGray, D., Japan's Gross National Cool. S mreže skinuto 28.

svibnja 2015. Sa: ttp://www.foreignpolicy.com/articles/2002/05/01/japans gross national cool

4.) PSY. Gangnam Style. (2013). S mreže skinuto 28. svibnja 2015.

Sa:http://en.wikipedia.org/wiki/Gangnam_Style

5.) Salon. Iyer, P. (2000). Why We Travel. S mreže skinuto 28. svibnja 2015. Sa: http://www.salon.com/2000/03/18/why/

6.) Kachru, B. (1982). The Other Tongue. Illinois: University of Illinois Press.

7.) Village Voice. Myers, R. New on the Hot 100 This Week. S mreže skinuto 28. svibnja 2015.

Sa: http://blogs.villagevoice.com/music/authors/robert myers/

8.) Nye, J. (2004). Soft Power: The Means to Success in World Politics. New York: Public Affairs.

9.) The New York Times. Talbot, M. (2012). The Year in Ideas: Pokemon Hegemon. S mreže skinuto 28. svibnja 2015. Sa: http://www.nytimes.com/2002/12/15/magazine/15POKE.html

10.) The Economist Johnson Blog. (2012). The Internet and Language Change. S mreže skinuto 28. svibnja 2015. Sa: http://www.economist.com/blogs/johnson/2012/12/internet-andlanguagechange

11.) Video file. (2012). PSY: (officialpsy). “Gangnam Style”. S mreže skinuto 28. svibnja 2015. Sa: http://www.youtube.com/watch?v=9bZkp7q19f0

12.) Lee, Sh., Moody, A. (2013). English in Asian Popular Culture. Sa: World English 1: 134-

137. Doi: $10.1111 /$ weng. 12012

12.) Ostler, N. (2010). The Last Lingua Franca: English Until the Return of Babel. New York: Walker \& Walker Company.

13.) Radumilo Tuksar, S. (2013). From Lingua Franca to Gangnam Style. FLTAL Proceedings

Book, IBU Publications, 1911.

\section{APPENDICIES:}

Appendix 1: Graph 1: Personal Report

Appendix 2: Graph 2: Personal Report

Appendix 3: Graph 3: Personal Report

\section{SAŽETAK:}

Cilj je ovoga istraživanja skrenuti pažnju na promjene engleskoga jezika koji je kao globalna lingua franca otvorio granice novome kulturnom fenomenu koji ga koristi za vlastitu promociju te penetraciju u druge kulture. Stoga je nužno razmotriti različiti kulturni sadržaj koji se zahvaljujući internetu promiče u Europi te vrši utjecaj na promjene korištenja engleskoga jezika. U tu svrhu poslužit ćemo se azijskim primjerom popularnoga pop-kulturnog fenomena.

Za potrebe ovoga istraživanja razmotrena su mišljenja studenta Sveučilišta Jurja Dobrile u Puli koji pohađaju obaveni kolegij Engleski jezik. Podvrgnuti su anketi koju je kreirala autorica ovoga rada te odgovarali na sljedeća pitanja: Mislite li da će se engleski nastaviti beskrajno širiti? Hoće li se u zemljama izvan anglofone grupe nastaviti učiti engleski? Možemo li očekivati promjene vezane uz engleski jezik kao takav obzirom na razne ekonomske i društvene promjene?

Na prva dva pitanja student su odgovorili pozitivno (61.6\% te $64.6 \%)$. Što se pak trećega pitanja tiče, $64.6 \%$ studenata vjeruje da će doći do promjene u engleskome jeziku obzirom na dinamične promjene koje na njega utječu. Na kraju, studenti su obrazložili svoja mišljenja što je u ovome radu i elaborirano. 